\begin{tabular}{|c|c|c|}
\hline$\exists$ & $\begin{array}{c}\text { International Journal of Current Research in } \\
\text { Biosciences and Plant Biology }\end{array}$ & \\
\hline $\begin{array}{l}\text { EXCELLENT } \\
\text { PUBLISHERS }\end{array}$ & 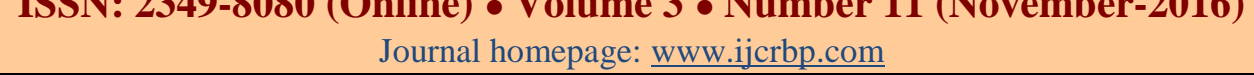 & \\
\hline
\end{tabular}

\title{
Effect of Ageing on Phosphatase Enzyme Activities in Vermicomposts of Different Organic Substrates
}

\author{
J. Devi ${ }^{1}$ and M. Prakash**
}

${ }^{1}$ Research \& Development Centre, Bharathiar University, Coimbatore-641 046, Tamil Nadu, India

${ }^{2}$ Department of Microbiology, Kanchi Shri Krishna College of Arts and Science, Kilambi, Kancheepuram-631 551, Tamil Nadu, India

*Corresponding author.

\section{A bstract}

Vermicompost prepared from teak leaf litter (TLL), paper mill sludge (PMS) and pressmud (PM) in combination with cowdung (1:1) using the epigeic earthworm, Perionyx ceylanensis for 60 days was stored in ambient conditions, then studied for selective enzyme activities at an interval of 10 days up to 40 days. Acid and alkaline phosphatase activities initially increased and started declining after 20 days in all the vermibed substrates. In teak leaf litter+cowdung vermicompost, acid phosphatase activity was $0.148,0.155,0.150,0.119$ and $0.094 \mathrm{~m}$ moles of phenol liberated/1 respectively on $0,10,20,30$ and 40 days after harvesting. Similar trend was also recorded in alkaline phosphatase activity in vermicomposts during storage. The decreased level of activity of phosphatases on $40^{\text {th }}$ day of storage was statistically significant.

\section{Introduction}

Earthworms restore and improve soil fertility and boost crop productivity by the use of their metabolic product vermicast. They excrete beneficial soil microbes, and secrete polysaccharides, proteins and other nitrogenous compounds into the soil. They promote soil fragmentation and aeration, and bring about soil turning and dispersion in farmlands. Worm activity can increase air-soil volume from $8-30 \%$. One acre of land can contain up to 3 million earthworms the activities of which can bring up to 8-10 tons of top soil to the surface (in the form of vermicast) every year (Tomati and Galli, 1995; Ghabbour, 1996).

Tomati et al. (1987) reported the presence of plant

\section{Article Info}

Accepted: 11 October 2016

Available Online: 06 November 2016

\section{Ke ywords}

Perionyx ceylanensis

Phosphatase activity

Vermibed substrates

Vermicompost growth hormones (auxins, gibberellins and cytokinins) in vermicompost. Moreover, vermicompost contains enzymes like amylase, lipase, cellulase and chitinase, which continue to break down organic matter in the soil (to release the nutrients and make it available to the plant roots) even after they have been excreted (Chaoui et al., 2003). Muscolo et al. (1999) also found an auxin-like effect of earthworm-worked humic substances on cell growth and nitrogen metabolism in Daucus carota. Increased level of $\mathrm{P}$ during vermicomposting is due to earthworm gut derived phosphatase activity and also increased microbial activity in the cast (Lee and Foster, 1991).

Krishnamoorthy (1990) reported that the rise in the level of $\mathrm{P}$ content during vermicomposting is probably due to 
mineralization and mobilization of $\mathrm{P}$ due to bacterial and faecal phosphatase activity of earthworms. Hence the activity of phosphatases is very essential even after harvesting of vermicompost. Considering this in the present study, acid and alkaline phosphatases activity in the vermicompost after harvesting has been carried out during storage up to 40 days.

\section{Materials and methods}

Teak leaf litter (TLL) was collected from an agroform near KSK College, Kanchipuram. The paper mill sludge (PMS) was procured from a private mill near Kanchipuram. The filter mud or pressmud (PM) was collected from Cheyyar Co-operative Sugar Mills Ltd., located in Thenthandalam, Anakkayur, Thiruvannamalai District, Tamil Nadu. The cowdung was collected from nearby cattle sheds in fresh form and allowed to stabilize for one week and used for the study.

The organic substrates, TLL, PMS and PM were subjected to initial decomposition in rectangular draining cement tanks of $75 \mathrm{~cm} \times 60 \mathrm{~cm} \times 45 \mathrm{~cm}$ size by sprinkling water, regular mixing and turning of the substrates for 20 days. The earthworm, Perionyx ceylanensis Mich. was mass multiplied in cow dung and used for vermicomposting studies. The ratio of organic substrate mix, i.e., 1:1 (50:50) proportion on dry weight basis was used in the present study. Accordingly, the predecomposed organic substrates were mixed with cowdung in 1:1 ratio on dry weight basis, transferred to vermibeds and moistened to hold $60-70 \%$ moisture content.

The vermicomposting studies were carried out for 60 days using $P$. ceylanensis in three replicates twice under controlled conditions. On $60^{\text {th }}$ day, the experiment was terminated and the vermicompost was harvested and sampled for phosphatase enzymes (day 1) viz., alkaline phosphatase and acid phosphatase were estimated from the vermicompost filtrates using the method of Lowry et al. (1954) up to 40 days at an interval of 10 days, i.e, on day $1,10,20,30$ and 40 . The results were statistically compared using Duncan's multiple range test.

\section{Results and discussion}

The increase of enzyme activities in vermibed substrates is mainly due to the increased surface area during fragmentation and decomposition, and increased microbial activity which has been reported by earlier workers (Tiwari et al., 1989). While studying the effect of different organic wastes, and microbial inoculants on chemical and biochemical properties of vermicompost, Pramanik et al. (2007) reported that cow dung was the best substrate for vermicomposting and the application of lime $(5 \mathrm{~g} / \mathrm{kg})$ and inoculation of microorganisms increased the nutrient content in vermicompost and also phosphatases and urease activities. In the present study cowdung was used along with organic substrates in 1:1 ratio.

In the present study, both acid and alkaline phosphatase activities initially increased and started declining after 20 days in all the vermibed substrates. In teak leaf litter+cowdung vermicompost, acid phosphatase activity was $0.148,0.155,0.150,0.119$ and $0.094 \mathrm{~m}$ moles of phenol liberated/l respectively on $0,10,20,30$ and 40 days after harvesting (Table 1). The acid phosphatase activity in paper mill sludge + cowdung vermicompost was $0.126,0.137,0.118,0.105$ and $0.089 \mathrm{~m}$ moles of phenol liberated/l respectively on $0,10,20,30$ and 40 days after harvesting. In pressmud + cowdung, it was $0.154,0.161,0.146,0.127$ and $0.113 \mathrm{~m}$ moles of phenol liberated/1 respectively on $0,10,20,30$ and 40 days after harvesting (Table 1). Similar trend was also recorded in alkaline phosphatase activity in vermicomposts during storage. The increase of acid and alkaline phosphatases up to 10-20 days storage was statistically significant; however, the activity started declining thereafter and the decreased level of activity of phosphatases was statistically significant.

Table 1. Acid phosphatase* activity during vermicomposting of different vermibed substrates using Perionyx ceylanensis.

\begin{tabular}{|c|c|c|c|c|c|}
\hline Vermicompost & \multicolumn{5}{|c|}{ Storage days } \\
\hline Teak leaf litter + cowdung & $0.148^{\mathrm{a}}$ & $0.155^{b}$ & $0.150^{\mathrm{ab}}$ & $0.119^{c}$ & $0.094^{\mathrm{d}}$ \\
\hline Pressmud + cowdung & $0.154^{\mathrm{a}}$ & $0.161^{\mathrm{a}}$ & $0.146^{\mathrm{b}}$ & $0.127^{\mathrm{c}}$ & $0.113^{\mathrm{d}}$ \\
\hline
\end{tabular}

(* $\mathrm{m}$ moles of phenol liberated / 1). The values with same alphabets between composting days are significantly different at $p=0.05$ level. 
Table 2. Alkaline phosphatase* activity during vermicomposting of different vermibed substrates using Perionyx ceylanensis.

\begin{tabular}{|c|c|c|c|c|c|}
\hline Vermicompost & \multicolumn{5}{|c|}{ Storage days } \\
\hline Teak leaf litter + cowdung & $0.087^{\mathrm{a}}$ & $0.092^{\mathrm{a}}$ & $0.084^{\mathrm{ab}}$ & $0.078^{b}$ & $0.066^{\mathrm{c}}$ \\
\hline Paper mill sludge + cowdung & $0.075^{\mathrm{a}}$ & $0.089^{b}$ & $0.080^{\mathrm{a}}$ & $0.074^{\mathrm{a}}$ & $0.059^{c}$ \\
\hline Pressmud + cowdung & $0.098^{\mathrm{a}}$ & $0.106^{\mathrm{a}}$ & $0.099^{\mathrm{a}}$ & $0.082^{\mathrm{b}}$ & $0.073^{c}$ \\
\hline
\end{tabular}

(* $\mathrm{m}$ moles of phenol liberated / 1). The values with same alphabets between composting days are not significantly different at $p=0.05$ level.

Thus phosphatase activity measurements provide an index of potential availability of phosphate in soil (Marshall et al., 1981). Pramanik et al. (2007) suggested that vermicomposting increased humic acids content and acid phosphatase activity in organic substrates and microbial inoculation further enhanced the rate of humification and enzyme activity. In the present study, after harvesting of vermicompost, the phosphatases activity is maintained by initial increase and then slow rate of declining hence enriching nutrients in vermicomposts.

\section{Conflict of interest statement}

Authors declare that they have no conflict of interest.

\section{References}

Chaoui, H. I., Zibilske, L. M., Ohno, T., 2003. Effects of earthworms casts and compost on soil microbial activity and plant nutrient availability. Soil Biol. Biochem. 35(2), 295-302.

Ghabbour, S. I., 1996. Earthworm in agriculture: A modern evaluation. Indian Rev. Ecol. Biol. Soc. 111(2), 259-271.

Krishnamoorthy, R. V., 1990. Mineralization of phosphorus by faecal phosphatases of some earthworms of Indian tropics. Proc. Indian Acad. Sci. (Anim. Sci.). 99, 509-518.
Lee, K. E., Foster, R. C., 1991. Soil Fauna and Soil Structure. Aust. J. Soil Res. 29, 745-776.

Lowry, O.H., Roberts, N.R., Mei-Ring, W. U., Hixon, W.S., Crawford, E.J., 1954. Phosphatase studies-Acid and alkaline phosphatase. J. Biol. Chem. 207, 19-37.

Marshall, G.P., Syers, J.K., Gregg, P.E.H., 1981. Plant availability of phosphorus in dead herbage ingested by surface casting earthworms. Soil Biol. Biochem. 13, 163-167.

Muscolo, A., Bovalo, F., Gionfriddo, F., Nardi, S., 1999. Earthworm humic matter produces auxin-like effects on Daucus carota cell growth and nitrate metabolism. Soil Biol. Biochem. 31, 1303-1311.

Pramanik, P., Ghosh, G.K., Ghosal, P.K., Banik, P., 2007. Changes in organic - C, N, P and $\mathrm{K}$ and enzymatic activities in vermicompost of biodegradable organic wastes under liming and microbial inoculants. Bioresour. Technol. 98, 2485-2495.

Tiwari, S.C., Tiwari, B.K., Mishra, R.R., 1989. Microbial population, enzyme activities and nitrogen-phosphoruspotassium enrichment in earthworm casts and in the surrounding soil of a pineapple plantation. Biol. Fertil. Soils. 8, 178-182.

Tomati, V., Galli. E., 1995. Earthworms, soil fertility and plant productivity. Acta Zool. Fenn. 196, 11-14.

Tomati, V., Grappelli, A., Galli, E., 1987. The presence of growth regulators in earthworm - worked wastes. In: Proceeding of International Symposium on Earthworms, Italy. $31^{\text {st }}$ March-5 ${ }^{\text {th }}$ April 1985. pp.423-436.

\section{How to cite this article:}

Devi, J., Prakash, M., 2016. Effect of ageing on phosphatase enzyme activities in vermicomposts of different organic substrates. Int. J. Curr. Res. Biosci. Plant Biol. 3(11), 115-117.

doi: http://dx.doi.org/10.20546/ijcrbp.2016.311.016 